\title{
Skolens betydning for det videre livsløpet
}

\author{
Over inngangsdøren på en skole \\ i Odense som ble bygd i 1907 står \\ det: «Vil du blivet noget må du lære \\ noget.» Denne setningen er langt \\ mer gyldig i dag enn den var for \\ over 100 år siden.
}

Ingen tidligere generasjon av barn og unge har vært mer avhengig av skolegangen sin enn den som vokser opp i dag. Dagens foreldre kan være helt sikre på én ting - at barna deres kommer til å måtte leve av skolegangen sin. Barnas videre utdanning, arbeidsdeltakelse, helse og sosiale deltakelse er avhengig av hvordan de mestrer skolen.

Aktiv deltakelse og læring i inkluderende fellesskap i skolen gir et godt grunnlag for videre utdanning, deltakelse i arbeidslivet, god helse og fravær av psykiske problemer, rus og kriminalitet. Dagens forskning viser at det er svært sterke sammenhenger mellom mestring i skolen og fremtidig livskvalitet. Av dem som ikke kommer gjennom videregående opplæring med studieeller yrkeskompetanse, er om lag $20 \%$ i Nav som 25-åringer. Disse unge voksne har ikke formell kompetanse, de har liten yrkeserfaring og de har opplevd mange nederlag i skolen. Sannsynligvis kommer de til å trenge støtte fra det offentlige resten av livet. De blir lett uføretrygdet, lever i gjennomsnitt kortere og bruker helsevesenet mer enn de som kommer gjennom skolen og inn i arbeidslivet.

Livsløpet avgjøres ikke først og fremst i den videregående opplæringen - det er grunnskolen som er marginaliserings- generatoren i samfunnet. Den kunnskapen og de ferdigheter du får med deg gjennom grunnskolen, er avgjørende for det videre utdanningsløpet og dermed livet ditt. Verdens ledende utdanningsforsker John Hattie dokumenterer at om du ikke har løst lesekoden når du er åtte år, kommer du sannsynligvis aldri til å bli en funksjonell leser. Videre vet vi at kun $13 \%$ av dem som går ut av grunnskolen i Norge med lavere karakterer enn 3 i gjennomsnitt, mestrer videregående opplæring. Vi kan si at $87 \%$ av disse får et nederlag som de aldri kommer til å glemme. Av minoritetsspråklige gutter i Oslo med dårligere gjennomsnittskarakter enn 3 fra grunnskolen har 30 \% fått en tiltale for kriminalitet før de er 20 år. Det kan hevdes at i kriminelle miljøer opplever de til en viss grad mestring, verdsetting og respekt, noe de sannsynligvis har møtt lite av i skolen.

Ikke bare er skolegangen viktig for den enkelte, den er også avgjørende for samfunnsøkonomien. Samfunnsøkonomer viser at kostnadene ved at så mange faller ut av utdanning og ikke kommer inn i arbeidslivet er formidable. For et årskull av dem som faller utenfor, utgjør kostnadene til hjelpe- og stønadsordninger i Nav samt mer bruk av helsetjenester ca. 15 milliarder kroner over et livsløp. Om vi fikk 100 ekstra ungdommer gjennom videregående opplæring og inn i arbeidslivet, ville besparelsene være på 40 millioner kroner per år i 42 år. I denne sammenhengen er ikke utdanning en utgift, det er en investering - sannsynligvis den viktigste investeringen et samfunn kan gjøre.

God læring og utvikling i skolen omfatter både det sosiale og det faglige fellesska- pet. Ved å lære fag i skolen, utvikles du som menneske, og ved å utvikle en god personlig og sosial karakter, har du et godt grunnlag for å lære noe. Denne samtidigheten i personlig, sosial og faglig læring er avgjørende. Skolen er ikke bare fag, den danner også mennesket. Det er viktig å understreke at den sosiale og den personlige utviklingen ikke primært handler om omsorg. Det handler i større grad om struktur, tydelige forventninger og læring av sosiale ferdigheter.

Læring gir opplevelsen av å være del av et fellesskap, og mestring gir motivasjon og lyst til å lære mer. Samtidig skal barn og unge også ha det godt og trives i skolen og barnehagen, og de skal ta ansvar for hverandre og seg selv. Det skal være press og trykk på læring, samtidig som det også kan arbeides med barns og unges moralske, personlige og sosiale utvikling og læring.

Hensikten med skole og utdanning er at alle får lære og får realisert sitt potensial innenfor et fellesskap. Barn og unge lærer og utvikler seg når de blir møtt av lærere med høy realkompetanse. Aldri tidligere har læreren vært viktigere for de unges fremtid enn i dag. I skolen foregår det mye lærings-og helsefremmende arbeid, og når lærerne lykkes, er skolen utvilsomt den viktigste forebyggende arenaen i samfunnet. Derfor bør skolen og lærerne løftes frem og ikke snakkes ned.

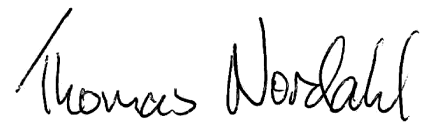

